\title{
Analisis Narasi Tentang Coming Out Pada Film Bertema LGBT di Netflix
}

\author{
Jeceline, Suzy Azeharie \\ jeceline@ymail.com,suzya@fikom.untar.ac.id
}

Fakultas Ilmu Komunikasi Universitas Tarumanagara

\begin{abstract}
In the recent years $L G B T$ issues are frequently discussed. Society assumes they cause social problem hence leading to rejection. LGBT communities are facing difficulties to express their sexual identity, usually called 'coming out'. Several films are narrating the 'coming out' process to capture the point of view from the members of this group. The purpose of this study is to examine the storyline about 'coming out' in LGBT-themed films according to Tzvetan Todorov's narrative analysis. This research uses qualitative method focusing on the narrative content in those movies. Data collection is done via observation and in-depth interview with two interviewees. From these findings combined with data analysis, it concluded the narrative storyline in films based on Tzvetan Todorov's theory are divided into three parts. It begins with equilibrium, then conflicts build up in the middle of the film, and finally the solution to equilibrium is found. 'Coming out' process and struggles are depicted from scenes and dialogues on the film which aligned with findings from the interviewees. The result of this study shows that every part in 'coming out' process are shown in Alex Strangelove film. Meanwhile there are two parts in 'coming out' process that are shown in Handsome Devil film.
\end{abstract}

Keywords: Tzvetan Todorov's narrative analysis, Netflix film, Coming Out

\begin{abstract}
Abstrak
Kelompok LGBT telah menjadi salah satu isu di dalam masyarakat yang menjadi isu panas. Masyarakat yang menolak menganggap bahwa kelompok ini dapat menimbulkan masalah sosial. Penolakan tersebut menyebabkan kelompok LGBT kerap menghadapi kesulitan dalam mengungkapkan identitas seksualnya atau sering disebut dengan 'coming out'. Banyak film yang saat ini mengangkat tentang coming out untuk menangkap sudut pandang kelompok tersebut. Penelitian ini bertujuan untuk mengetahui narasi alur cerita tentang 'coming out' pada film bertema LGBT menurut teori Tzvetan Todorov. Teori yang digunakan pada penelitian adalah teori komunikasi massa dan teori narasi Tzvetan Todorov. Penulis menggunakan pendekatan kualitatif dan metode analisis narasi. Melalui observasi terhadap dua film dan wawancara mendalam dengan dua informan menunjukkan narasi alur cerita pada film yang diteliti menurut Tzvetan Todorov dibagi menjadi tiga bagian. Dimulai dengan adanya keseimbangan kemudian terjadi konflik pada pertengahan film hingga akhirnya ditemukan jalan keluar untuk kembali pada keseimbangan pada akhirnya. Proses 'coming out' dapat dilihat pada beberapa adegan dan dialog yang terdapat pada film. Hasil penelitian menunjukkan bahwa pada film Alex Strangelove ditemukan semua tahapan proses 'coming out'. Sedangkan pada film Handsome Devil ditemukan dua tahapan proses coming out.
\end{abstract}

Kata Kunci: analisis naratif Tzvetan Todorov, film Netflix, Coming Out 


\section{Pendahuluan}

Kelompok LGBT menurut José Fernando Serrano Amaya dan Oriol Ríos González telah menjadi salah satu isu yang sering dibahas dalam dunia politik dan masyarakat selama beberapa dekade terakhir (Amaya dan González, 2019: 371). Di Indonesia LGBT menjadi isu yang sering dibahas oleh masyarakat (Ramadhanti dan Azeharie, 2020: 302). Berdasarkan survei yang dilakukan oleh Williams Institute pada 174 negara, terdapat 131 negara yang mengalami peningkatan dalam penerimaan komunitas LGBT. Peningkatan tersebut menunjukkan bahwa semakin banyak negara yang menerima keberadaan komunitas LGBT (NBC News, 2019).

Meskipun begitu menurut Chatterjee Subhrajit kelompok LGBT kerap mengalami diskriminasi, pelecehan dan intoleransi karena orientasi seksual mereka. Kelompok LGBT yang hidup di tengah-tengah masyarakat yang menganut nilai heteronormatif mengalami kesulitan karena homoseksualitas dianggap sebagai sesuatu yang terlarang. Kelompok LGBT yang tidak mendapatkan dukungan dari keluarga dan teman-teman akan mengalami kesulitan dalam diskriminasi yang dialami dalam kehidupan sehari-hari (Subhrajit, 2014: 317-318, 322).

Penolakan dari masyarakat ataupun dari orang-orang menyebabkan kelompok LGBT menutup identitas seksualnya. Sehingga menurut Laurie Heatherington dan Justin A. Lavner dalam Renée Perrin-Wallqvist dan Josephine Lindblom bagi kelompok LGBT untuk mengungkapkan identitas seksualnya atau biasa disebut dengan coming out kepada keluarga dan sekitarnya menjadi suatu tantangan yang berat (Perrin-Wallqvist dan Lindblom, 2015: 468). Padahal menurut Kirsten McLean dalam Nicholas A. Guittar coming out menjadi salah satu faktor penting dalam menciptakan identitas seksual yang sehat bagi kelompok LGBT (Guittar, 2013: 169).

Film menurut Elisa Gunawati et al. menjadi salah satu bentuk media massa yang digunakan untuk menyampaikan informasi kepada masyarakat melalui adegan yang menjadi suatu kesatuan yang utuh. Pembuat film kerap memiliki sudut pandang yang berbeda terhadap kelompok LGBT sehingga menarik jika di angkat ke dalam film. (Gunawati et al., 2020: 16). Menurut Laili Mustaghfiro film dapat digunakan sebagai wujud representasi dari masyarakat karena isi film mengandung pesan yang dapat dipelajari dan disampaikan kepada khalayak dengan mudah (Mustaghfiro, 2018: 6).

Penyampaian pesan suatu film kepada penonton menurut Aziz Maulana dan Catur Nugroho dapat dilihat dari sisi narasi yang digunakan. Narasi yang digunakan juga berhubungan dengan cara bercerita, penyajian fakta pada film dan juga cara bercerita kepada penonton. Menurut Tzvetan Todorov narasi memiliki bagian awal, tengah dan akhir (Maulana dan Nugroho, 2020: 39). Pada penelitian ini penulis menggunakan teori komunikasi massa dan teori narasi Tzvetan Todorov.

Rumusan masalah pada penelitian ini adalah bagaimana narasi alur cerita tentang coming out pada film bertema LGBT di Netflix menurut analisis narasi Tzvetan Todorov. Sedangkan tujuan penelitiannya adalah untuk mengetahui narasi alur cerita tentang coming out pada film bertema LGBT di Netflix menurut analisis narasi Tzvetan Todorov. Selain itu penulis melakukan penelitian ini karena belum ada penelitian yang membahas tentang analisis narasi tentang coming out pada film bertema LGBT di Netflix. 


\section{Metode Penelitian}

Pada penelitian ini penulis menggunakan metode penelitian kualitatif deskriptif. Penulis menggunakan metode penelitian kualitatif karena ingin meneliti tentang gambaran coming out kelompok LGBT pada narasi film bertema LGBT di Netflix. Penulis menggunakan metode analisis naratif untuk penelitian ini. Analisis naratif menurut Eriyanto dalam Siti Shadrina Azizaty dan Idola Perdini Putri digunakan untuk memahami struktur cerita pada narasi film ataupun novel. Analisis naratif menggunakan teks sebagai suatu cerita, baik itu merupakan karya fiksi seperti puisi, dongeng, novel, film ataupun merupakan sebuah fakta seperti berita. Teks yang digunakan adalah susunan kejadian, tata urutan kejadian dan bagian dari kejadian yang dipilah kemudian dibuang (Azizaty dan Putri, 2015: 54). Penulis menggunakan metode penelitian analisis naratif karena ingin meneliti alur cerita dan dialog yang terdapat pada dua film bertema LGBT tentang coming out yang dipilih oleh penulis.

Penulis melakukan pengumpulan data dengan melakukan wawancara semiterstruktur yang merupakan bentuk in-depth interview karena penulis meminta narasumber untuk memberikan pendapat agar mendapatkan jawaban yang lebih mendalam (Sugiyono, 2015: 320). Kemudian penulis juga melakukan dokumentasi melalui tangkapan layar melalui tangkapan layar untuk mengumpulkan informasi yang akan diteliti lebih lanjut (Susanti, 2017: 31). Lalu penulis melakukan observasi nonpartisipan karena penulis hanya berperan sebagai pengamat pada dua film tentang coming out bertema LGBT di Netflix. Penulis juga menggunakan studi kepustakaan yaitu dengan mengkaji literatur seperti buku dan jurnal (Ainin, 2017: 42).

Pada penelitian ini, penulis melakukan analisis data dengan teknik analisis naratif yaitu rangkuman tulisan yang meliputi kejadian-kejadian yang terjadi dari waktu ke waktu yang kemudian disusun dalam urutan awal, tengah dan akhir (Ariani, 2019: 52). Penulis menggunakan teknik analisis naratif karena dapat membantu penulis dalam memberikan makna yang terdapat pada narasi. Pada penelitian ini penulis menggunakan analisis naratif Tzvetan Todorov. Penulis melakukan triangulasi untuk menguji validitas data yang didapatkan. Penulis menggunakan teknik triangulasi sumber dikarenakan penulis akan mengumpulkan data dari sumber-sumber yang berbeda. Sementara, penulis menggunakan triangulasi metode dikarenakan penulis menggunakan teknik pengumpulan data yang berbeda-beda.

\section{Hasil Temuan dan Diskusi}

Struktur narasi menurut Tzvetan Todorov dalam Nurul Haq Bilqi Risyani terbagi menjadi tiga bagian. Alur cerita awal merupakan bagian yang keseimbangan (equilibrium), cerita tengah adalah bagian yang membentuk proses narasi dan timbul konflik, alur cerita akhir adalah menunjukkan ketika equilibrium muncul kembali dalam cerita (Risyani, 2020: 37-38). Teori narasi menurut Tzvetan Todorov dimodifikasi oleh Nick Lacey menjadi lima bagian yaitu kondisi keseimbangan dan keteraturan, gangguan (disruption) terhadap keseimbangan, kesadaran terjadi gangguan, upaya untuk memperbaiki gangguan dan pemulihan menuju keseimbangan (Eriyanto, 2013: 47).

Pada film Alex Strangelove alur cerita awal dimulai dengan perkenalan tokoh Alex dan Claire. Mulanya hubungan mereka hanya sebatas teman proyek namun seiring berjalannya waktu berkembang menjadi sepasang kekasih. Selama berpacaran mereka belum pernah melakukan hubungan intim dan berencana untuk 
melakukannya dalam waktu dekat. Suatu malam Alex bertemu dengan seorang lakilaki bernama Elliot. Sejak pertemuan pertama mereka timbul rasa ketertarikan antara Alex dan Elliot. Hal tersebut juga membuat Alex mempertanyakan orientasi seksualnya. Lalu alur cerita tengah terjadi gangguan pada keseimbangan cerita film ketika Alex menyadari perasaannya kepada Elliot dan menciumnya. Bagian yang menunjukkan adanya kesadaran terhadap gangguan dapat dilihat pada adegan ketika Alex akhirnya mengakui pada Claire bahwa sebenarnya ia adalah seorang gay. Bagian selanjutnya menunjukkan upaya menuju keseimbangan cerita ketika Alex berbincang dengan Claire terkait orientasi seksualnya dan meminta maaf padanya. Pada alur cerita akhir cerita kembali seimbang ketika Alex bertemu kembali dengan Elliot di malam pesta dansa. Awalnya Alex tidak berani berdansa dengan Elliot karena ia takut diperhatikan oleh teman-teman sekolahnya. Namun akhirnya ia memberanikan dirinya dan mencium Elliot di tengah-tengah banyak orang.

Sedangkan pada film Handsome Devil alur cerita awal bermula dengan perkenalan tokoh Ned, seorang laki-laki gay yang dikucilkan oleh teman-teman sekolahnya karena orientasi seksualnya. Ia kemudian bertemu Conor, seorang murid pindahan baru dan atlet rugby yang akan menjadi teman sekamarnya. Hubungan pertemanan mereka terjalin karena memiliki selera musik yang sama dan hubungan pertemanan mereka pun terjalin. Lalu gangguan terhadap keseimbangan cerita pada alur cerita tengah dimulai ketika Ned secara tidak sengaja melihat Conor masuk ke dalam bar gay usai merayakan kemenangan tim rugby-nya dalam pertandingan. Conor juga diancam oleh salah satu anggota tim rugby-nya untuk tidak berteman dengan Ned jika tidak ingin alasan sebenarnya ia pindah sekolah dibongkar. Bagian kesadaran terhadap gangguan cerita terjadi ketika Ned mengumbar ke teman-teman sekolahnya bahwa Conor adalah seorang gay.

Bagian selanjutnya menunjukkan upaya menuju keseimbangan cerita ketika Ned pergi mencari Conor. Ned meyakinkan Conor untuk mengikuti final pertandingannya dan mendorongnya untuk berani mengungkapkan dirinya yang sebenarnya. Alur cerita akhir film Handsome Devil menunjukkan pemulihan pada keseimbangan yang dapat dilihat pada adegan ketika Conor dan Ned datang ke final pertandingan rugby. Conor pun akhirnya mengakui kepada tim rugby-nya bahwa ia adalah seorang gay dan alasan sebenarnya ia pindah sekolah adalah karena di sekolah lamanya ia secara terus menerus diejek homo oleh teman-teman sekolahnya. Cerita berakhir dengan ia dan timnya melanjutkan pertandingan dan memenangkannya.

Pada penelitian ini penulis ingin mencari gambaran coming out yang terdapat yang ditunjukkan melalui narasi kedua film tersebut. Pada proses coming out terdapat beberapa tahapan yang akan dilalui oleh suatu individu yaitu tahapan awareness, exploration, acceptance, commitment dan integration (Oktaviana et al., 2020: 26-28). Proses coming out yang dilalui oleh setiap orang beragam. Pada penelitian ini penulis melakukan observasi pada dua film bertema LGBT dan wawancara dengan dua narasumber yaitu Monty P. Satiadarma dan Dede Oetomo sebagai informan pendukung. Penulis menemukan beberapa adegan yang menunjukkan tahapan-tahapan pada proses coming out.

Tahapan awareness dapat dilihat pada alur cerita awal film Alex Strangelove yaitu ketika Alex dan Elliot bercerita berdua sembari berbaring di tempat tidur dan membicarakan tentang impian mereka. Mereka tiba-tiba terdiam dan saling memandang satu sama lain. Menurut Antonia F. Hamilton memandang satu sama lain dalam waktu lama dapat diartikan sebagai bentuk cinta dan ketertarikan 
(Hamilton, 2016: 2). Adegan tersebut menunjukkan adanya ketertarikan secara seksual yang dirasakan oleh Alex kepada Elliot.

Gambar 1. Adegan Alex dan Elliot saling bertatapan di ranjang $(25: 28$ - 26:00)

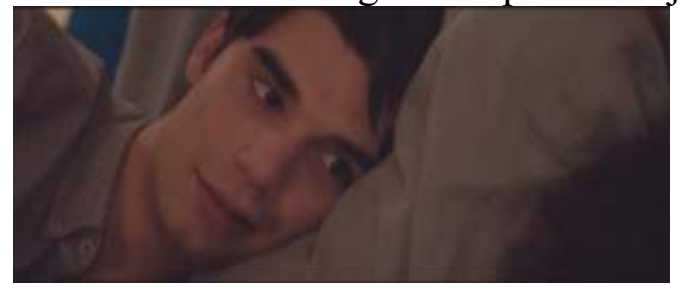

Sumber: Netflix

Tahapan exploration dapat dilihat pada alur cerita awal film Alex Strangelove yaitu ketika Alex sedang berada di rumahnya dan mengambil beberapa kotak sereal. Saat sedang memperhatikan kotak sereal tersebut tiba-tiba tulisannya perlahan berubah menjadi kata lain yang berhubungan dengan kata gay, heteroseksual dan biseksual. Alex terdiam sejenak dan mengatakan pada dirinya bahwa dirinya adalah seorang biseksual. Adegan tersebut menunjukkan kesadaran dan rasa keingintahuan Alex terhadap orientasi seksualnya.

Gambar 2. Adegan Alex melihat kotak sereal (42:25 - 43:23)

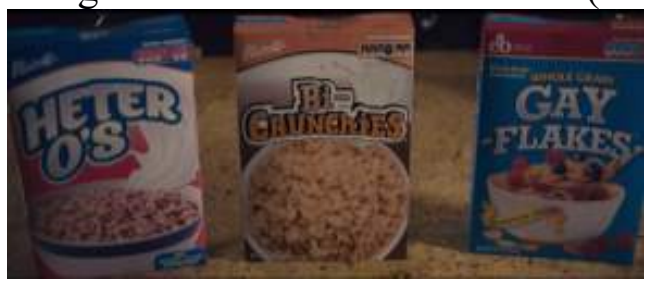

Sumber: Netflix

Tahapan acceptance dapat dilihat pada alur cerita tengah film Alex Strangelove yaitu ketika Alex pergi ke rumah Claire dan berbincang dengannya di mobil. Alex mengaku bahwa orang yang disukainya adalah Elliot. Ia merasa bahwa dirinya adalah gay sejak lama dan pikiran tersebut akan berhenti ketika ia bertemu dengan gadis yang tepat dan gadis tersebut adalah Claire. Alex takut akan kehilangan Claire apabila mengaku sebagai gay. Adegan tersebut menunjukkan penerimaan identitas seksual yang dilakukan oleh Alex.

Gambar 3. Adegan Alex menyadari dirinya gay sejak lama (1:23:15 - 1:25:48)

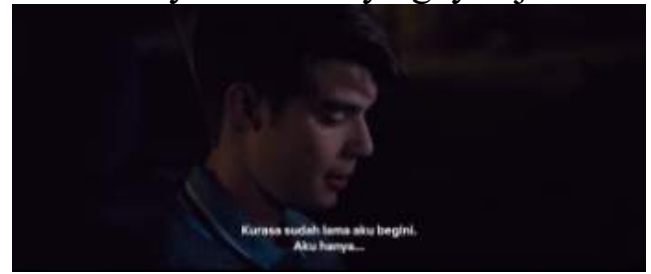

Sumber: Netflix

Tahapan commitment terdapat pada kedua film yang diobservasi oleh penulis. Pada film Alex Strangelove tahapan commitment ditunjukkan pada adegan ketika Alex bertemu dengan Elliot lagi setelah sekian lama. Ketika Elliot menanyakan alasan mereka tidak bertemu selama beberapa waktu, Alex mengatakan kepada Elliot 
bahwa ia harus memikirkan beberapa hal. Adegan ini menunjukkan ketika Alex menegaskan identitas seksualnya sebagai seorang gay.

Gambar 4 Adegan Alex dan Elliot bertemu kembali (87:19 - 88:27)

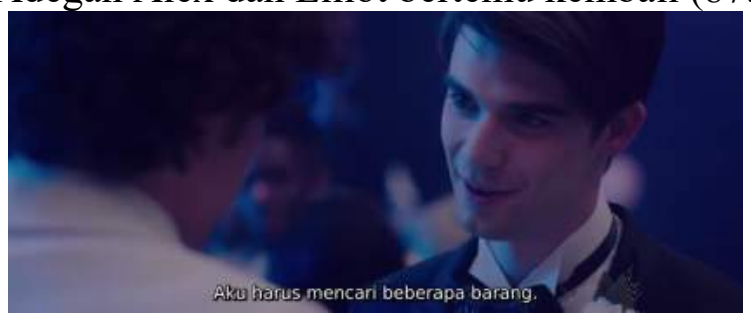

Sumber: Netflix

Sedangkan pada film Handsome Devil tahapan ini ditunjukkan pada adegan ketika Ned pergi menemui Conor yang hilang dan tidak hadir di pertandingan rugbynya. Ned mendorong Conor untuk mengungkapkan dirinya kepada orang-orang. Ia juga mengatakan pada Conor bahwa dirinya dapat menjadi seorang gay dan juga pemain rugby. Mendengar perkataan Ned akhirnya Conor memutuskan untuk mengungkapkan dirinya yang sebenarnya kepada orang lain.

Gambar 5. Adegan Ned mendorong Conor untuk mengungkapkan diri (78:50 $80: 41)$

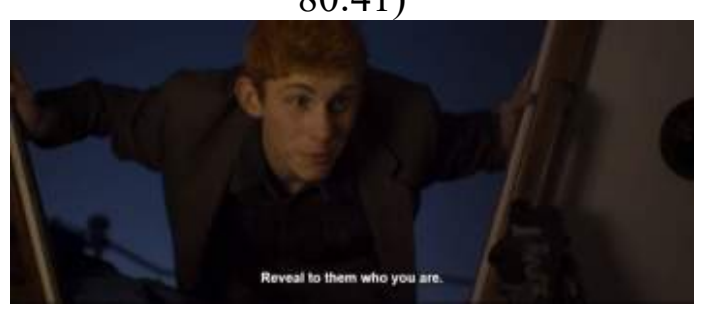

Sumber: Netflix

Tahapan integration juga terdapat pada kedua film yang diobservasi oleh penulis. Pada film Alex Strangelove tahapan integration ditunjukkan pada adegan ketika Alex mengejar Elliot untuk menahannya agar tidak pergi kemudian mencium Elliot di depan teman-teman sekolahnya. Mereka pun kemudian berdansa bersama. Adegan tersebut menunjukkan ketika Alex akhirnya mengungkapkan identitas seksualnya kepada lingkungannya.

Gambar 6. Adegan Alex dan Elliot berdansa di depan banyak orang (1:29:20 -

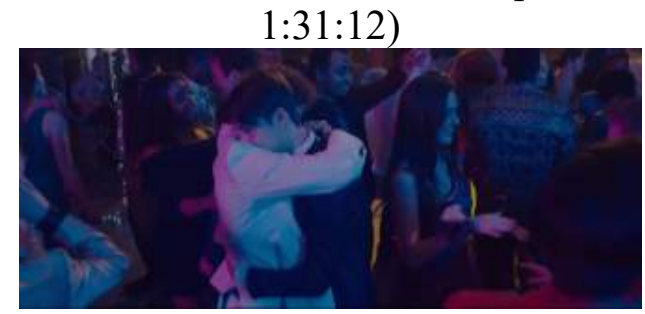

Sumber: Netflix

Sedangkan pada film Handsome Devil tahapan ini ditunjukkan pada adegan ketika Conor dan Ned bersama-sama kembali ke sekolah. Ia mengakui bahwa dirinya adalah gay dan alasan ia pindah sekolah adalah karena murid-murid di sekolah sebelumnya secara terus menerus menghina dirinya sebagai seorang homo. 
Gambar 7. Adegan Conor mengakui ke tim rugby-nya (82:01 - 86:04)

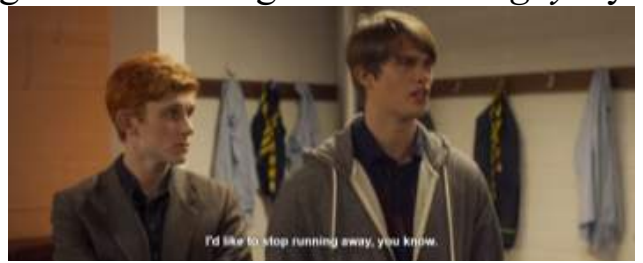

Sumber: Netflix

Bagi Dede Oetomo yang telah melakukan coming out sebagai gay juga melewati tahapan-tahapan yang serupa. Tahapan awareness terjadi ketika ia merasakan perasaan berbeda kepada sesama jenis sejak berumur delapan tahun. Meskipun ia memiliki teman-teman perempuan ia tidak memiliki keinginan untuk memacari mereka. Tahapan exploration Dede terjadi ketika ia mencoba memacari perempuan. Namun ia tidak tertarik secara seksual kepada perempuan tersebut melainkan menganggapnya hanya sebatas seorang kakak.

Tahapan acceptance dilalui oleh Dede ketika ia akhirnya menyadari perasaannya dan secara perlahan mulai berani mengungkapkan perasaannya terhadap laki-laki ketika ia baru satu setengah tahun kuliah di Amerika. Tahapan commitment ia lalui ketika ia akhirnya meyakinkan perasaannya terhadap laki-laki dan lebih berani bertindak. Pada tahapan ini juga ia mulai menjalani hubungan dengan laki-laki. Tahapan integration dilalui Dede ketika ia mengungkapkan diri kepada teman-teman perempuan dan orang tuanya tentang seksualitasnya. Bahkan ia juga pernah tampil di publik bersama pasangannya dulu ketika salah satu stasiun TV swasta RCTI datang ke rumahnya untuk acara 'Angin Malam'.

Namun pada kedua film terdapat hambatan dan tantangan yang terjadi saat suatu individu melakukan coming out. Salah satunya di alur cerita tengah film Alex Strangelove pada adegan yang menunjukkan Alex di masa lalu. Dulu ia pernah mendapatkan perundungan karena mengalami ereksi saat sedang mandi bersama teman-teman sekolahnya. Ia diejek homo oleh mereka. Oleh karena itu ia menyembunyikan identitas seksualnya. Menurut Caroline B. R. Evans and Mimi V. Chapman kelompok anak muda LGBT seringkali menjadi korban dalam perundungan. Panggilan sebutan tertentu terhadap kelompok tersebut menjadi salah satu bentuk perundungan (Evans dan Chapman, 2014: 644). Menurut Balamanter dalam Theresia Bening Sarasati lingkungan sekitar dapat mempengaruhi keterbukaan seorang gay (Sarasati, 2020: 21).

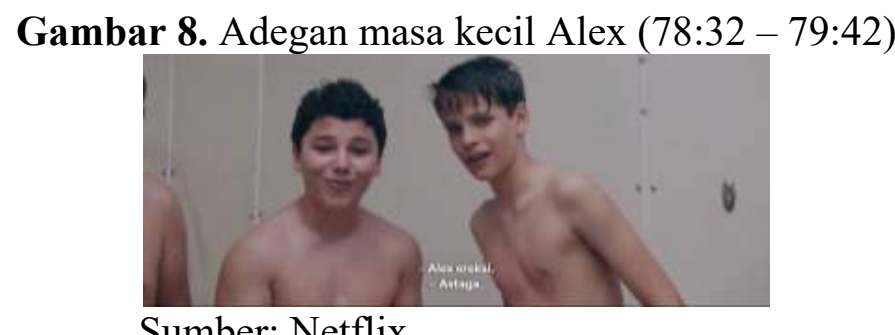

Lalu pada film Handsome Devil hambatan dan tantangan di alur cerita tengah ketika Conor diancam oleh salah satu anggota tim rugby-nya untuk tidak berteman dengan Ned jika tidak ingin alasan sebenarnya ia pindah sekolah dibongkar. Menurut Christopher K. Belousa et al. kelompok gay dan lesbian seringkali merasakan perasaan negatif karena harus berbohong pada diri sendiri. (Belousa et al., 2014: 65). 
Gambar 9. Adegan Conor diancam akan disebarkan rahasianya (52:07 - 53:32)

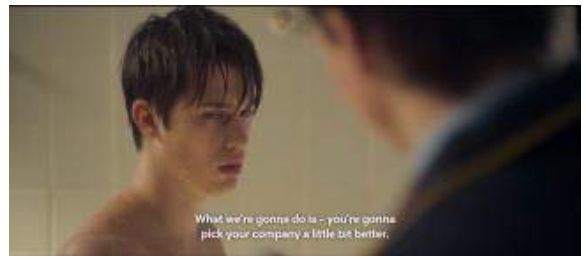

Sumber: Netflix

Tantangan dan hambatan yang dihadapi individu dalam melakukan coming out menurut Monty P. Satiadarma bermacam-macam. Coming out sulit untuk dilakukan karena adanya penolakan dari orang terdekat ataupun lingkungannya. Hambatan juga dapat terjadi karena merasa tidak selara dengan keyakinan agama yang dianut namun di lain pihak tidak mampu mengatasi kenyataan perasaan berbeda yang ia miliki. Selain itu lingkungan sosial, pendidikan, pengajaran hingga pada aturan hukum juga dapat menghambat proses coming out pada suatu individu.

\section{Simpulan}

Dua film yang diobservasi oleh penulis memiliki susunan narasi cerita yang sesuai dengan model narasi Tzvetan Todorov. Film-film tersebut terbagi menjadi tiga alur kemudian mengikuti modifikasi narasi cerita menurut Nick Lacey yang dibagi menjadi lima bagian. Kemudian kedua film menunjukkan gambaran coming out melalui beragam adegan. Pada narasi film Alex Strangelove ditemukan semua tahapan pada proses coming out. Sedangkan pada film Handsome Devil ditemukan dua tahapan pada proses coming out. Selain itu pada kedua film juga terdapat adegan-adegan yang menunjukkan hambatan dan tantangan yang dihadapi oleh kelompok LGBT dalam melakukan coming out.

Penulis memiliki beberapa saran. Secara akademis penelitian kedepannya dapat dilakukan dengan menganalisis film bertema LGBT lainnya dan dapat dilakukan dengan mewawancarai narasumber lainnya yang ahli dalam bidang perfilman ataupun tentang LGBT. Sedangkan secara praktis film-film bertema LGBT tentang coming out sebaiknya diperbolehkan untuk ditonton oleh masyarakat untuk memberikan edukasi dan juga gambaran tentang kelompok LGBT serta sebaiknya diperbolehkan ditonton oleh masyarakat dengan batasan umur tertentu.

\section{Ucapan Terima Kasih}

Pada bagian ini penulis mengucapkan terima kasih dosen pembimbing serta para narasumber yang bersedia dalam memberikan informasi mendalam, bimbingan, masukan, bantuan dan motivasi sehingga penulis dapat menyelesaikan penelitian ini tepat waktu.

\section{Daftar Pustaka}

Ainin, Qurrotun. (2017). Pengaruh Model Cooperative Learning Tipe Course Review Horay (CRH) Terhadap Keaktifan Belajar Siswa (Studi Kasus Pada Siswa Kelas XIPS 2 SMA Bina Dharma Bandung Tahun Pelajaran 2016/2017). Skripsi. Bandung: Fakultas Keguruan dan Ilmu Pendidikan Universitas Pasundan. 
Amaya, José Fernando Serrano dan Oriol Ríos González. (2019). Introduction to the Special Issue: Challenges of LGBT research in the 21st century. 34(4). 371381.

Ariani, Dian Risca. (2019). Analisis Kelayakan Nasabah Dalam Pemberian Pembiayaan Musyarakah Untuk Meningkatkan Ekonomi Masyarakat (Study Kasus Di Bmt Sahara Kauman Tulungagung). Skripsi. Fakultas Ekonomi dan Bisnis Islam Institut Agama Islam Neger Tulungangun.

Azizaty, Siti Shadrina \& Idola Perdini Putri. (2018). Analisis Narasi Tzvetan Todorov pada Film Sokola Rimba. 2(1). 51-67.

Belousa, Christopher K. et al. (2015). Gay Male Adaptation in the Coming-Out Process. 19(1). 55-71.

Eriyanto. (2013). Analisis Naratif: Dasar-dasar dan Penerapannya dalam Analisis Teks Berita Media. Jakarta: Kencana.

Evans, Caroline B. R. \& Mimi V. Chapman. (2014). Bullied Youth: The Impact of Bullying Through Lesbian, Gay, and Bisexual Name Calling. 84(6). 644-652

Guittar, Nicholas A. (2013). The Meaning of Coming Out: From Self-Affirmation to Full Disclosure. 9(3). 169-187.

Gunawati, Elisa et al. (2020). Representasi Gay Dalam Film Moonlight. 2(1). 15-26

Hamilton, Antonia F. (2016). Gazing at Me: The Importance of Social Meaning in Understanding Direct-Gaze Cues. 371(1686). 1-6.

Maulana, Azis \& Nugroho, Catur. (2018). Nasionalisme dalam Narasi Cerita Film (Analisis Narasi Tzvetan Todorov pada Film Habibie \& Ainun). 2(1). 37-49

Mustaghfiro, Laili. (2018). Analisis Naratif Nilai Sosial Film My Stupid Boss (Analisis Model Tzvetan Todorov). Skripsi. Surabaya: Fakultas Dakwah dan Komunikasi Universitas Islam Negeri Sunan Ampel Surabaya.

NBC News. (2019). LGBTQ Acceptance Grew Globally Over Past Four Decades but Not Everywhere. <https://www.nbcnews.com/feature/nbc-out/lgbtqacceptance-grew-globally-over-past-four-decades-not-everywhere-n1080706>

Oktaviana, Elizabeth Rida et al. (2020). Coming Out pada Kaum Lesbian di Semarang. 9(1). 23-29.

Perrin-Walqvist, Renée \& Josephine Lindblom. (2015). Coming Out as Gay: A Phenomenological Study About Adolescents Disclosing Their Homosexuality to Their Parents. 43(3). 467-480.

Ramadhanti, Aureliya \& Suzy Azeharie. (2020). Penerimaan LGBT oleh Tempat $\begin{array}{llll}\text { Ibadah. Jurnal } & \text { Koneksi. }\end{array}$ https://journal.untar.ac.id/index.php/koneksi/article/view/8146/0

Risyani, Nurul Haq Bilqi. (2020). Analisis Narasi Tzvetan Todorov dalam Film Keluarga Cemara sebagai Komunikasi Keluarga. Skripsi. Malang: Fakultas Ilmu Sosial dan Ilmu Politik Universitas Muhammadiyah Malang.

Sarasati, Theresia Bening. (2020). Representasi Identitas Homoseksual Dalam Film Taiwan "Dear Ex". Skripsi. Surabaya: Fakultas Ilmu Sosial dan Illmu Politik Universitas Airlangga.

Subhrajit, Chatterjee. (2014). Problems Faced by LGBT People in the Mainstream Society: Some Recommendations. 1(5). 317-331

Sugiyono. (2015). Metode Penelitian Pendidikan. Bandung: Penerbit Alfabeta.

Susanti, Septi Dewi. (2017). Integrasi Nilai-Nilai Demokrasi Dalam Pembelajaran IPS di SMP Negeri 13 Yogyakarta. Skripsi. Yogyakarta: Fakultas Ilmu Sosial Universitas Negeri Yogyakarta. 